02 Royal Netherlands Institute for Sea Research

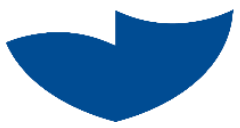

This is a postprint of:

Le Guitton, M.; Soetaert, K.; Sinninghe Damsté, J.S. \& Middelburg, J.J. (2017). Biogeochemical consequences of vertical and lateral transport of particulate organic matter in the southern North Sea: A multiproxy approach. Estuarine, Coastal and Shelf Science, 165, 117-127

Published version: https://dx.doi.org/10.1016/..ecss.2015.09.010

Link NIOZ Repository: www.vliz.be/imis?module=ref\&refid=251130

[Article begins on next page]

The NIOZ Repository gives free access to the digital collection of the work of the Royal Netherlands Institute for Sea Research. This archive is managed according to the principles of the Open Access Movement, and the Open Archive Initiative. Each publication should be cited to its original source - please use the reference as presented.

When using parts of, or whole publications in your own work, permission from the author(s) or copyright holder(s) is always needed. 


\title{
Biogeochemical consequences of vertical and lateral transport of particulate organic matter in the southern North Sea: a multiproxy approach.
}

\section{Le Guitton ${ }^{1 a}$, K. Soetaert ${ }^{1}$, J. S. Sinninghe Damsté ${ }^{2,3}$ and J. J. Middelburg ${ }^{1,3}$}

1. NIOZ Royal Netherlands Institute for Sea Research, Department of Ecosystem Studies, P.O. Box 140, 4400 AC Yerseke, The Netherlands

2. NIOZ Royal Netherlands Institute for Sea Research, Department of Marine Organic Biogeochemistry, P.O. Box 59, 1790 AB Den Burg, Texel, The Netherlands

3. Department of Earth Sciences, Faculty of Geosciences, Utrecht University, P.O. Box 80021, 3508 TA Utrecht, The Netherlands

a. Corresponding author: marie.leguitton@gmail.com

\begin{abstract}
Vertical and lateral transports are of importance in continental shelf systems such as the North Sea and play a major role in the processing of organic matter. We investigated the biogeochemical consequences of these transports on particulate organic matter at the molecular level in the southern North Sea. We analysed suspended particulate matter and surface sediments for organic carbon, pigments and phospholipid derived fatty acids at 10 stations sampled in September 2011 along the particle transport route. The particulate organic matter in both suspended particulate matter and surface sediment was mainly from marine phytoplankton origin but of fresher quality in the water column. Particulate organic matter quality did not change from south to north in the suspended particulate matter, whereas it
\end{abstract}


clearly decreased towards the north in the surface sediments, reflecting a decreased intensity of benthic-pelagic coupling. However, we also observed strong deposition of fresh organic matter in the northern station denoting that occasionally, intense benthic-pelagic coupling can occur. Finally, our study highlights the necessity to use a multiproxy approach covering multiple characteristic time scales, when investigating both suspended particulate matter and surface sediments.

Keywords: Particulate organic matter; biogeochemistry; biomarkers; transport processes; benthic-pelagic coupling; North Sea.

\section{Introduction}

Continental shelves account for more than $20 \%$ of the total marine organic matter primary production and are thus highly productive ecosystems (Gattuso et al., 2005). Part of this produced carbon is respired on the continental shelf, a small part is buried and the remainder is exported to the open ocean. Continental shelves also receive relatively large amounts of terrestrially-derived organic matter from rivers and estuaries (Bianchi, 2011), such as in the southeastern part of the North Sea (Rhine-Meuse-Scheldt rivers outflow) (e.g. Eleveld et al., 2008). In addition, continental shelf systems in temperate areas, such as the North Sea, account for a significant part of oceanic carbon dioxide uptake (e.g. Thomas et al., 2005; Borges, 2005) and global denitrification (Codispoti et al., 2001). Moreover these ecosystems are important with respect to harvestable resources but are also subject to major anthropogenic disturbances, especially in the North Sea (Halpern et al., 2008).

Continental shelves are characterized by substantial vertical and horizontal transport vectors. Due to their shallow depths, continental shelf systems are characterised by an intense benthicpelagic coupling, where the benthic compartment receives detritus and biological particles 
settling out of the water column and returns, with some delay, dissolved material in the form of dissolved inorganic carbon and nutrients, consuming significant quantities of oxygen in the process (Soetaert et al., 2000). Another mode of benthic-pelagic coupling consists of the temporary retention of pelagically produced organic matter particles in the sediments, by successive deposition and erosion cycles, e.g. as induced by tidal currents.

In addition to vertical interactions, continental shelf systems such as the North Sea are also characterized by across and along shelf exchange of water and material (De Haas, 1997). In the North Sea, the residual currents are directed from the southern North Sea via the frontal systems and the German Bight to the Skagerrak area (Otto et al., 1990). Particles are transported along this residual current and most accumulation eventually occurs in the Skagerrak, the depositional area of the North Sea (De Haas, 1997; Dauwe and Middelburg, 1998). The combination of the residual flow and the repeated cycles of deposition of particles and resuspension of sediment is called organic matter spiralling, a concept that has been extensively investigated in rivers and estuaries (Newbold et al., 1981; Newbold et al., 1982; Newbold, 1992), but to date has not received focus in shelf areas. If important, then particle transport is significantly delayed relative to residual current velocities because of temporary deposition and retention in the sediments, and as a result extensive processing of organic matter will occur, with major consequences for its molecular composition, its availability to organisms and the functional biodiversity of its heterotrophic consumers.

In the present study, we investigated the composition of particulate organic matter (POM) in surface seawater and surface sediments to assess the biogeochemical consequences of POM transport (both vertical and lateral) in the southern North Sea. Degradation rates differ consistently among organic compounds (Cowie and Hedges, 1994, Veuger and van Oevelen, 2011; Veuger et al., 2012), and the quality of POM can thus be studied over a wide spectrum of organic matter degradation states, by analysing multiple levels of the 'biomarkers pyramid' 
(see Bianchi and Canuel, 2011), i.e. bulk organic carbon, elemental composition (CN-molar ratio) and biomarker composition (pigments and phospholipid derived fatty acids). Linking the biochemical composition to calculated indicators of organic matter quality, our results are interpreted in terms of the intensity and predominant mode of benthic-pelagic coupling.

\section{Material and methods}

\subsection{Study area and sampling strategy}

Ten stations were sampled in the Southern North Sea in September 2011 with R.V. Pelagia

(Tab.1). The stations were chosen to study the gradient in POM quality along the general transport route of sedimentary organic matter in the southern North Sea (Lohse et al., 1995; Van Raaphorst and Malschaert, 1996; Dauwe and Middelburg, 1998; Fig.1). Stations (St.) 02 and 07 were located in the primary production area (sensu Dauwe and Middelburg, 1998), whereas St. 20 in the German Bight, St. 30 in Oyster Grounds and St. 62 and 65 in the Skagerrak, were located in deposition areas (Fig. 1).

Water samples were taken at $5 \mathrm{~m}$ depth using the ship's non-toxic pumping device (Aquaflow) and filtered to collect Suspended Particulate Matter (SPM) on GF/6 filters (1-3 $\mu \mathrm{m}$ pore size) for pigment analysis and $0.70 \mu \mathrm{m} \mathrm{GF} / \mathrm{F}$ filters for bulk and PLFA analyses. For sediment samples, a multi-corer (Octopus type) with four cores of $100 \mathrm{~mm}$ diameter was deployed. The sediment cores were directly sliced onboard, per $\mathrm{cm}$ down to $10 \mathrm{~cm}$ deep, using a manual core slicer. In this study, we focused on the first layer $(0-1 \mathrm{~cm})$ of surface sediment (SS) for the analyses. The SPM and SS samples were stored at $-20^{\circ} \mathrm{C}$ prior analyses, except SPM and SS pigment samples, which were stored at $-80^{\circ} \mathrm{C}$. 


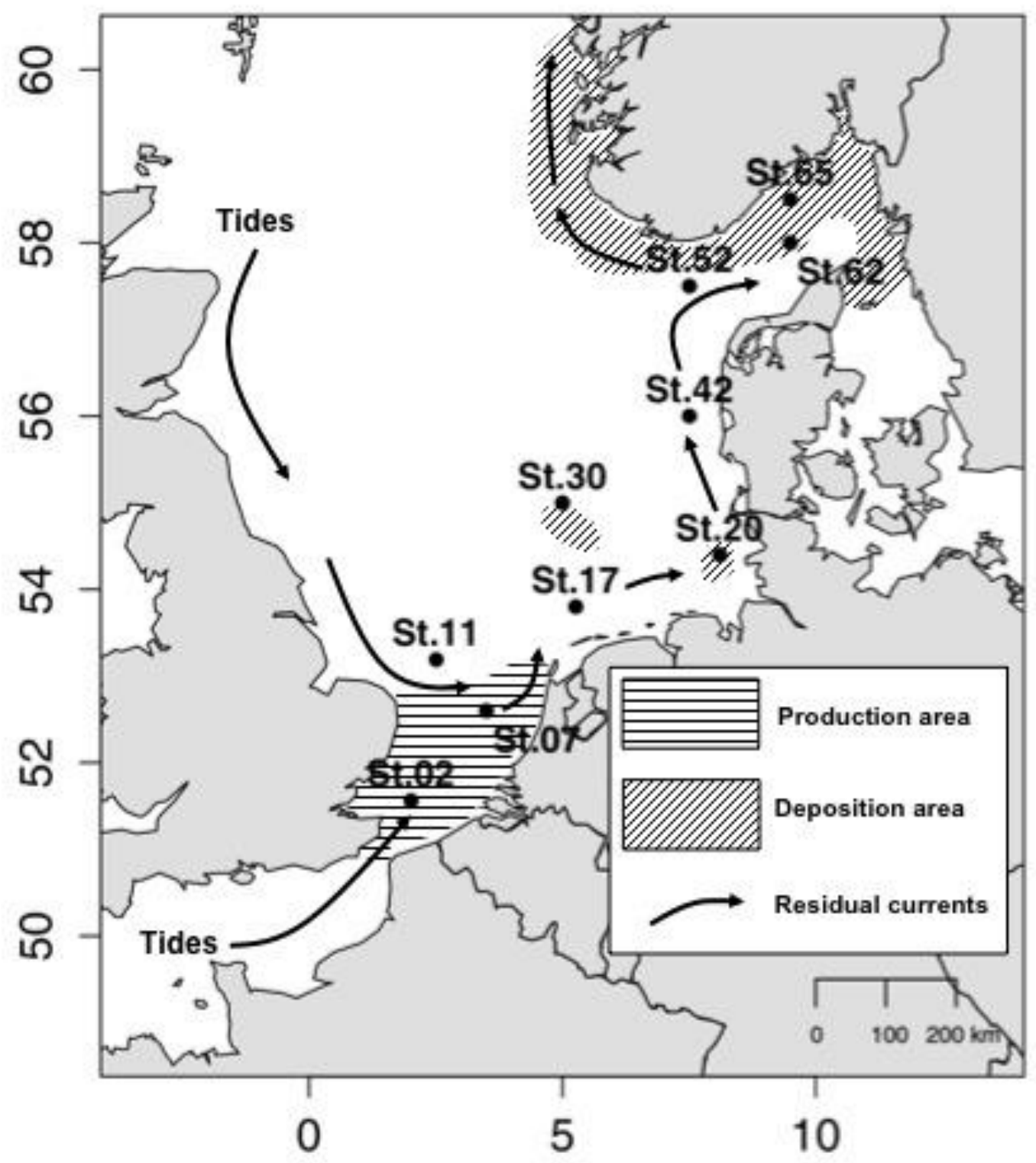

Fig. 1. Map of the North Sea with sampling stations adapted from Dauwe and Middelburg (1998)

\subsection{Analyses}

Analyses of total nitrogen, organic carbon (OC), pigments, and phospholipid derived fatty acids (PLFAs) were performed. For nitrogen and OC analysis, SPM and SS samples were acidified with $6 \mathrm{M} \mathrm{HCl}$ to remove inorganic carbon and analysed using a Carlo Elba elemental analyser NA-1500 (Nieuwenhuize et al., 1994). For pigments, SPM and SS 
samples were freeze-dried and extracted with $10 \mathrm{ml}$ acetone/water (90/10; v/v). After centrifugation, $50 \mu \mathrm{l}$ of this extract was analyzed for pigments on a C18-column with use of reversed phase chromatography (Jeffrey et al., 1997). The pigments were detected by a Photodiode Array and Fluorescence detector and identified based on their retention times and by comparison of their absorption spectra to a homemade library of absorption spectra of pure pigments standards (DHI, Denmark). The PLFAs were extracted from SPM and SS samples using the method described in Boschker et al. (1999) modified from Bligh and Dyer (1959). Porosity was determined by weight loss after freeze-drying, accounting for salt precipitation in the saline pore water. Grain size distribution was determined using a Malvern Mastersizer 2000 particle analyzer. The SPM values are reported as the mean of two samples collected in the same area at the same time with standard deviation, for pigments and PLFAs at all stations and for Particulate Organic Carbon (POC) and $\mathrm{CN}$ ratio $(\mathrm{CN}-\mathrm{r})$ at St. 20. The results for surface sediments are for single samples. SS values for pigments and PLFAs are expressed in $\mu \mathrm{g} \cdot \mathrm{gdw}^{-1}$ with gdw for gram dry weight.

\subsection{PLFA nomenclature}

Each identified individual PLFA compound is expressed using the notation $\mathrm{C} A: B \omega x$, where $A$ is the number of carbons, $B$ is the number of double bonds, and $x$ is the position of the first double bond relative to the terminal methyl group. Saturated fatty acid (SFA) concentrations were calculated as the sum of all individual compounds with no double bonds (notation $\mathrm{CA}: B$ ), mono-unsaturated fatty acids (MUFA) as the sum of all individual compounds with

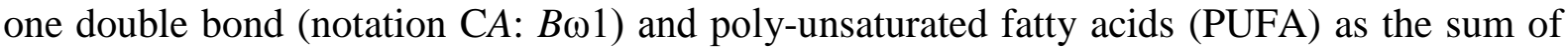
all individual compounds with two or more double bonds (notation $\mathrm{C} A$ : $B \omega x$ with $x \geq 2$ ) (Budge et al., 2006). Branched fatty acid (Br-FA) concentration was calculated as the sum of

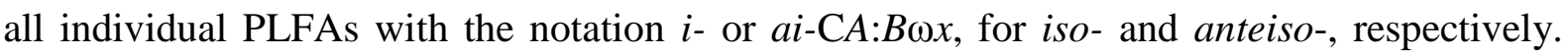


Finally the total PLFA concentration was calculated as the sum of all identified individual PLFAs in both SPM and SS samples. SFA, MUFA, PUFA and Br-FA are expressed as the percentage of total PLFAs (\%-total PLFAs).

\subsection{POM quality derived parameters}

The North Sea is a complex system, where transport of water and matter varies spatially and temporally (e.g. Eleveld et al., 2008; Dobrynin et al., 2010; Tiessen et al., 2014). Therefore quantifying the timescales on which organic matter transport and degradation processes occur, remains a challenge. Nevertheless based on the timescales of molecule degradation rates (Cowie and Hedges, 1994, Veuger and van Oevelen, 2011; Veuger et al., 2012), we explore POM quality in terms of OM degradation and microbial reworking by POM quality parameters as follows (Fig. 2):

i. Short time scales - Pigments have higher degradation rates compared to lipids and we used pigments derived parameters to assess the freshness of POM. Therefore the chlorophyll $a$ to phaeopigment ratio (CHLA/PHAEOs), with the phaeopigments defined as the sum of pheophytin and phaeophorbide, and the intact to total pigments ratio (ITPIG) (Woulds and Cowie, 2009), where intact pigments are the sum of chlorophyll a, alloxanthin, diatoxanthin, zeaxanthin and $\beta$ carotene were calculated. High ratios indicate fresh $\mathrm{OM}$.

ii. Intermediate time scales - Lipids have a lower degradation rate compared to pigments, but a higher one compared to bulk organic matter and amino acids (Veuger et al., 2012). Thus, the composition of the PLFA pool in terms of SFA, MUFA, PUFA and Br-FA was used to investigate POM quality and to assess bacterial biomass (Bechtel and Schubert, 2009; Christodoulou et al., 2009). Low percentage of PUFA and high percentage of SFA indicate more extensive OM 
degradation and high percentages of MUFA and Br-FA indicate higher bacterial biomass.

iii. Long time scales - The CN-ratio was used to represent POM quality on the long time scale. Indeed the $\mathrm{CN}$-ratio increases from Redfield up to values as high as 10 with ongoing marine OM decomposition (Henrichs, 2005).

To investigate the degree of benthic-pelagic coupling, the difference between SPM and SS values were calculated for each POM quality parameters as follows:

Difference of $i=S P M$ value of $i-S S$ value of $i$

where i represents the POM quality parameters. The closer to 0 , the more intense is the benthic-pelagic coupling.

\subsection{Principal Component Analysis (PCA)}

To examine whether POM quality was influenced and/or controlled by the same factors in SPM and SS samples, a Principal Component Analysis was carried out using the software R (R Development Core Team, 2008). The PCA was performed based on POM quality parameters calculated for SPM and SS samples, i.e. chlorophyll $a$ to phaeopigments ratio and intact to total pigments ratio for the short time scale; saturated fatty acid, mono-unsaturated fatty acid, poly-unsaturated fatty acid and branched fatty acid for the intermediate time scale; and the $\mathrm{CN}$-ratio for the long time scale. 


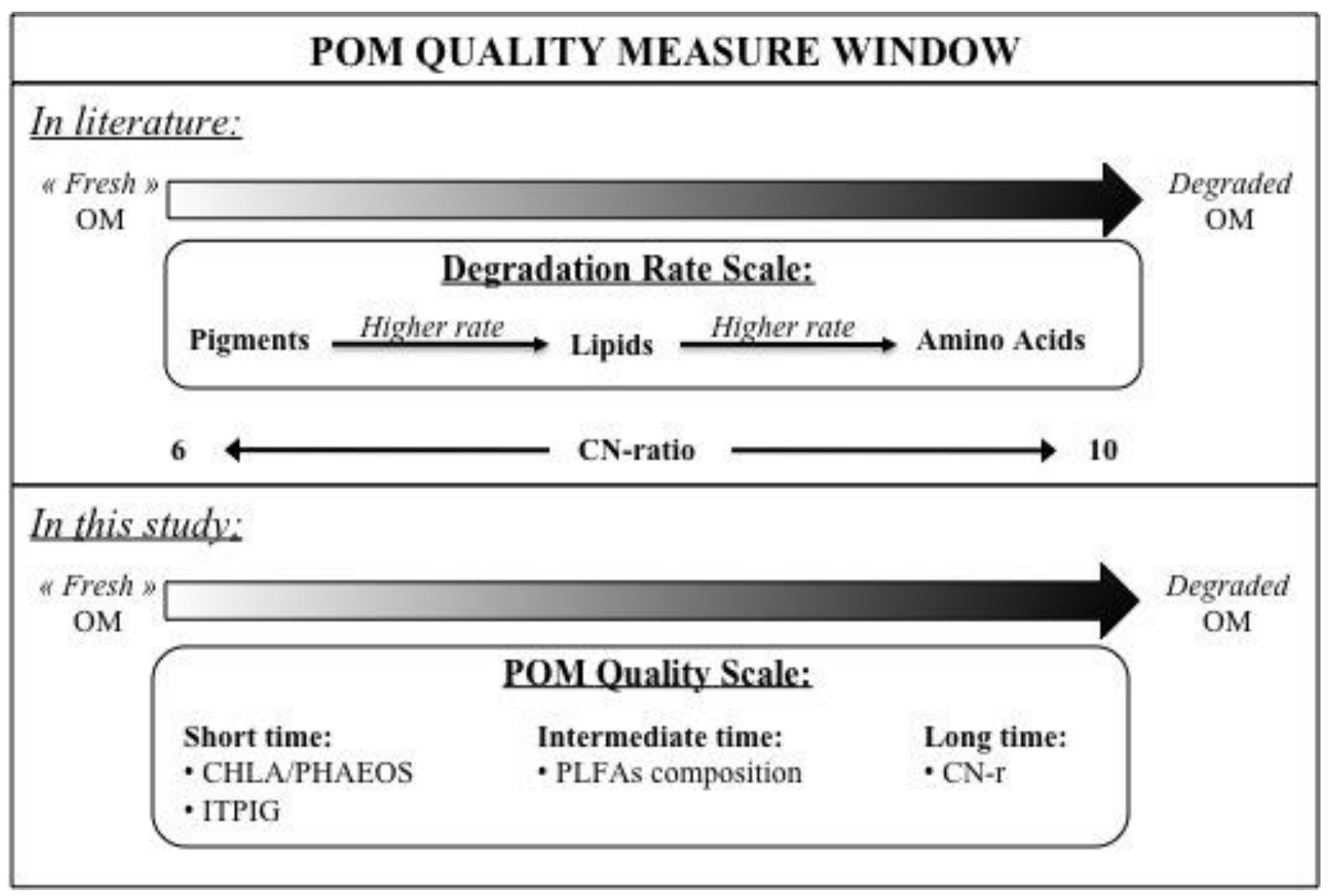

Fig. 2. Schematic picture of POM quality measure window. The degradation rate scale is based on results found by Cowie and Hedges (1994), Veuger and van Oevelen (2011) and Veuger et al. (2012). The variation of the CN-ratio (CN-r) has been reported by Henrichs (2005). CHLA/PHAEOs $=$ Chlorophyll a to phaeopigments ratio, ITPIG = Intact to total pigments, PLFAs = Phospholipid derived Fatty Acids. 


\section{Results}

\subsection{Station main characteristics}

The characteristics of the stations are listed in Tab. 1. From St. 02 to 42, the water depth was relatively shallow $(<60 \mathrm{~m})$ whereas $\mathrm{St} .52,62$ and 65 were $>200 \mathrm{~m}$ deep. The surface water temperature and salinity varied between stations. The highest temperature $\left(18^{\circ} \mathrm{C}\right)$ and salinity (35) were found at the southernmost St. 02. The northern stations St. 52 and 65 had the lowest temperature $\left(14^{\circ} \mathrm{C}\right)$. Station 20 had the lowest salinity (29), probably due to its location close to the Elbe estuary. The organic carbon in SPM ranged from $0.11 \mathrm{mg}-\mathrm{C} . \mathrm{l}^{-1}$ at St. 30 and 52 to $0.58 \pm 0.16 \mathrm{mg}-\mathrm{C} . \mathrm{l}^{-1}$ at St. 20. In SS samples, total organic carbon increased from St. 02 $(0.02 \%)$ to St. 65 (2.28\%). Porosity was relatively constant in the shallowest stations (from St. 02 to 42 ), averaging $0.3 \pm 0.1$ and was higher in the deepest stations (St. 52, 62 and 65), averaging $0.7 \pm 0.1$. At St. 02 , coarse (50\%) and medium sand (44\%) particles dominated the composition of the sediment. From St. 07 to 42, the sediment consisted predominantly of medium and fine sand (around 30-70\%), except for St. 30, where the grain size was dominated by fine and very fine sand (68\% and 24\%, respectively). At St. 52, 62 and 65, the silt content was the highest ( $\geq 50 \%)$.

\subsection{Particulate Organic Matter composition}

In SPM samples, the pigment composition was dominated by chlorophyll $a\left(1.10 \mu \mathrm{g} . \mathrm{l}^{-1} \pm 0.27\right.$ on average) (Tab. 2). Other chlorophylls (sum of Chlorophyll $b, c$ and $c_{3}$ ), fucoxanthin and peridinin were found in lower concentration $\left(0.35 \mu \mathrm{g} . \mathrm{l}^{-1} \pm 0.14,0.27 \mu \mathrm{g} . \mathrm{l}^{-1} \pm 0.14\right.$ and 0.04 $\mu \mathrm{g} . \mathrm{l}^{-1} \pm 0.03$, on average, respectively). Chlorophyll $c_{3}$ was not detected (below detection limit) at St. 20, and neither was peridinin at St. 07. The degradation products of chlorophyll. $a$, i.e. phaeophytin $a$ and phaeophorbide $a$, showed high concentrations at St. $20\left(0.15 \mu \mathrm{g} .1^{-1} \pm\right.$ 0.03 and $0.27 \mu \mathrm{g} .1^{-1} \pm 0.04$, respectively). The PLFAs were dominated at all stations by 
$\mathrm{C} 22: 6 \omega 3$ and $\mathrm{C} 20: 5 \omega 3\left(0.67 \mu \mathrm{g}-\mathrm{C} .1^{-1} \pm 0.38\right.$ and $0.34 \mu \mathrm{g}-\mathrm{C} .1^{-1} \pm 0.13$, on average respectively). The PLFAs $\mathrm{C} 16: 1 \omega 7 \mathrm{c}$ and $\mathrm{C} 18: 1 \omega 7 \mathrm{c}$ were also present at concentrations of

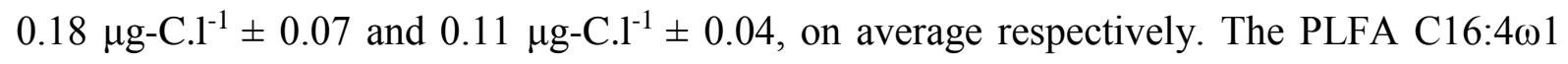
was only detected at St. $02,11,17$ and 42 at low concentrations $\left(\leq 0.05 \mu \mathrm{g}-\mathrm{C} . \mathrm{l}^{-1}\right)$. The branched fatty acids, such as i-C14:0, i-C15:0, ai-C15:0, i-C17:0 and ai-C17:0 were also found in low concentrations $\left(\leq 0.05 \mu \mathrm{g}-\mathrm{C} . \mathrm{l}^{-1}\right)$ and not at all stations.

In SS samples, both pigments and PLFA concentrations increased from St. 02 to 65 (Tab.3). The pigment composition was dominated by chlorophyll $a$ in the southernmost stations (St. 02, 07 and 11), while the phaeopigments dominated the pigment composition from St. 20 to 65. At St. 17, the concentrations of chlorophyll $a$ and phaeopigments were similar $(0.16$ $\left.\mu \mathrm{g} \cdot \mathrm{gdw}^{-1}\right)$. The concentration of fucoxanthin was also relatively high in the SS samples, ranging from $0.03 \mu \mathrm{g} . \mathrm{gdw}^{-1}$ at St. 02 to $0.81 \mu \mathrm{g} . \mathrm{gdw}^{-1}$ at St. 65 . Chlorophyll $c_{3}$ and peridinin were not detected in the SS samples and chlorophyll $b$ was only detected at St. 30, 52 and 65 in relatively low concentrations $\left(\leq 0.2 \mu \mathrm{g} \cdot \mathrm{gdw}^{-1}\right)$. The PLFAs showed relatively high concentrations of $\mathrm{C} 16: 1 \omega 7 \mathrm{c}$ and $\mathrm{C} 18: 1 \omega 7 \mathrm{c}$ at all stations, followed by ai-C15:0, $\mathrm{C} 22: 6 \omega 3$ and $\mathrm{C} 20: 5 \omega 3$. The branched fatty acids, such as i-C14:0, i-C15:0, ai-C15:0, i-C17:0 and ai-C17:0 were also found in high concentrations, even if some, like i-C17:0, were not detected at all stations. 
Tab. 1. Main characteristics of the stations.

\begin{tabular}{|c|c|c|c|c|c|c|c|c|c|c|c|}
\hline & & St.02 & St.07 & St.11 & St.17 & St.20 & St.30 & St.42 & St.52 & St.62 & St.65 \\
\hline Latitude & ${ }^{\circ} \mathrm{N}$ & 51.56 & 52.60 & 53.19 & 53.80 & 54.40 & 55.00 & 56.00 & 57.50 & 58.00 & 58.50 \\
\hline Longitude & ${ }^{\circ} \mathrm{E}$ & 2.01 & 3.50 & 2.51 & 5.26 & 8.10 & 5.00 & 7.50 & 7.50 & 9.50 & 9.50 \\
\hline Depth & $\mathrm{m}$ & 55 & 33 & 32 & 35 & 21 & 41 & 24 & 213 & 304 & 546 \\
\hline Temperature & ${ }^{\circ} \mathrm{C}$ & 18 & 17 & 16 & 17 & 17 & 15 & 17 & 14 & 15 & 14 \\
\hline Salinity & & 35 & 35 & 34 & 34 & 29 & 35 & 34 & 32 & 32 & 31 \\
\hline \multicolumn{12}{|l|}{ SPM } \\
\hline POC & $\mathrm{mg}-\mathrm{C} . \mathrm{l}^{-1}$ & 0.15 & 0.13 & 0.14 & 0.22 & $0.58 \pm 0.16$ & 0.11 & 0.15 & 0.11 & 0.14 & 0.14 \\
\hline \multicolumn{12}{|l|}{ SS } \\
\hline TOC & $\%$ wt & 0.02 & 0.03 & 0.06 & 0.10 & 0.11 & 0.12 & 0.07 & 1.17 & 1.42 & 2.28 \\
\hline Porosity & & 0.2 & 0.3 & 0.3 & 0.3 & 0.3 & 0.4 & 0.3 & 0.6 & 0.6 & 0.7 \\
\hline Coarse sand & $\%$ 500-1000 $\mu \mathrm{m}$ & 50 & 3 & 3 & 1 & 0 & 0 & 1 & 0 & 0 & 0 \\
\hline Medium sand & $\%$ 250-500 $\mu \mathrm{m}$ & 44 & 68 & 64 & 43 & 31 & 4 & 36 & 0 & 1 & 0 \\
\hline Fine sand & $\% 125-250 \mu \mathrm{m}$ & 2 & 30 & 33 & 49 & 62 & 68 & 55 & 14 & 5 & 6 \\
\hline Very fine sand & $\%$ 63-125 $\mu \mathrm{m}$ & 1 & 0 & 0 & 3 & 7 & 24 & 7 & 36 & 21 & 18 \\
\hline Silt & $\%<63 \mu \mathrm{m}$ & 4 & 0 & 0 & 4 & 0 & 4 & 0 & 50 & 73 & 75 \\
\hline
\end{tabular}


Tab. 2. Pigments and PLFAs in SPM samples. Results are presented as mean \pm standard deviation. ND $=$ not detected

\begin{tabular}{|c|c|c|c|c|c|c|c|c|c|c|c|}
\hline & & St.02 & St.07 & St.11 & St.17 & St.20 & St.30 & St.42 & St.52 & St.62 & St.65 \\
\hline Pigments & $\mu \mathrm{g} . \mathrm{l}^{-1}$ & & & & & & & & & & \\
\hline Chl.a & & $1.16 \pm 0.02$ & $0.59 \pm 0.01$ & $1.09 \pm 0.00$ & $1.35 \pm 0.05$ & $1.22 \pm 0.12$ & $1.09 \pm 0.01$ & $1.51 \pm 0.05$ & $0.90 \pm 0.03$ & $1.28 \pm 0.03$ & $0.82 \pm 0.00$ \\
\hline Chl.b & & $0.14 \pm 0.00$ & $0.09 \pm 0.00$ & $0.09 \pm 0.00$ & $0.05 \pm 0.00$ & $0.20 \pm 0.01$ & $0.12 \pm 0.00$ & $0.14 \pm 0.00$ & $0.10 \pm 0.00$ & $0.11 \pm 0.01$ & $0.15 \pm 0.00$ \\
\hline Chl.c3 & & $0.04 \pm 0.00$ & $0.03 \pm 0.00$ & $0.05 \pm 0.00$ & $0.05 \pm 0.00$ & ND & $0.10 \pm 0.01$ & $0.07 \pm 0.01$ & $0.05 \pm 0.00$ & $0.08 \pm 0.01$ & $0.05 \pm 0.00$ \\
\hline Feo & & $0.04 \pm 0.00$ & $0.02 \pm 0.00$ & $0.03 \pm 0.00$ & $0.03 \pm 0.00$ & $0.15 \pm 0.03$ & $0.02 \pm 0.00$ & $0.04 \pm 0.00$ & $0.01 \pm 0.00$ & $0.02 \pm 0.00$ & $0.02 \pm 0.00$ \\
\hline Fuco & & $0.33 \pm 0.00$ & $0.13 \pm 0.01$ & $0.35 \pm 0.00$ & $0.34 \pm 0.02$ & $0.33 \pm 0.04$ & $0.20 \pm 0.01$ & $0.55 \pm 0.01$ & $0.15 \pm 0.00$ & $0.23 \pm 0.01$ & $0.10 \pm 0.00$ \\
\hline PLFAs & $\mu \mathrm{g}-\mathrm{C} . \mathrm{l}^{-1}$ & & & & & & & & & & \\
\hline i-C14:0 & & ND & ND & ND & ND & ND & ND & ND & ND & ND & ND \\
\hline i-C15:0 & & $0.03 \pm 0.00$ & 0.02 & 0.02 & $0.04 \pm 0.02$ & $0.03 \pm 0.00$ & ND & 0.01 & ND & 0.02 & $0.02 \pm 0.01$ \\
\hline $\begin{array}{l}\text { ai-C15:0 } \\
\text { C16:1w7 }\end{array}$ & & 0.02 & ND & ND & 0.02 & $0.03 \pm 0.00$ & ND & ND & ND & 0.02 & 0.02 \\
\hline $\mathrm{c}$ & & $0.26 \pm 0.05$ & $0.14 \pm 0.06$ & $0.15 \pm 0.14$ & $0.25 \pm 0.11$ & $0.21 \pm 0.01$ & $0.08 \pm 0.00$ & $0.14 \pm 0.05$ & $0.11 \pm 0.01$ & $0.21 \pm 0.13$ & $0.26 \pm 0.09$ \\
\hline $\mathrm{C} 18: 1 \omega 7 \mathrm{c}$ & & $0.15 \pm 0.02$ & $0.08 \pm 0.02$ & $0.08 \pm 0.07$ & $0.19 \pm 0.08$ & $0.15 \pm 0.01$ & $0.06 \pm 0.01$ & $0.09 \pm 0.04$ & $0.07 \pm 0.01$ & $0.13 \pm 0.07$ & $0.14 \pm 0.05$ \\
\hline $\mathrm{C} 20: 5 \omega 3$ & & $0.41 \pm 0.11$ & $0.27 \pm 0.02$ & $0.25 \pm 0.20$ & $0.59 \pm 0.26$ & $0.33 \pm 0.05$ & $0.39 \pm 0.24$ & $0.46 \pm 0.11$ & $0.14 \pm 0.00$ & $0.26 \pm 0.12$ & $0.28 \pm 0.12$ \\
\hline $\mathrm{C} 22: 6 \omega 3$ & & $0.64 \pm 0.18$ & $0.52 \pm 0.12$ & $0.38 \pm 0.29$ & $1.60 \pm 0.77$ & $0.25 \pm 0.00$ & $0.51 \pm 0.03$ & $0.77 \pm 0.34$ & $0.40 \pm 0.06$ & $0.76 \pm 0.28$ & $0.84 \pm 0.24$ \\
\hline
\end{tabular}


Tab. 3. Pigments and PLFAs in SS samples. Results are from single value. ND = not detected.

\begin{tabular}{|c|c|c|c|c|c|c|c|c|c|c|c|}
\hline & & St.02 & St.07 & St.11 & St.17 & St.20 & St.30 & St.42 & St.52 & St.62 & St.65 \\
\hline Pigments & $\mu \mathrm{g} \cdot \mathrm{gdw}^{-1}$ & & & & & & & & & & \\
\hline Chl.a & & 0.04 & 0.12 & 0.28 & 0.16 & 0.16 & 0.17 & 0.09 & 0.64 & 1.16 & 1.44 \\
\hline Chl.b & & ND & ND & ND & ND & ND & 0.01 & ND & 0.01 & ND & 0.02 \\
\hline Chl.c & & 0.01 & 0.02 & 0.03 & 0.02 & 0.02 & 0.02 & 0.01 & 0.07 & 0.10 & 0.14 \\
\hline Chl.c3 & & ND & ND & ND & ND & ND & ND & ND & ND & ND & ND \\
\hline $\mathrm{Feo}$ & & 0.01 & 0.01 & 0.04 & 0.05 & 0.04 & 0.09 & 0.04 & 0.40 & 0.94 & 0.93 \\
\hline Fuco & & 0.03 & 0.07 & 0.18 & 0.09 & 0.09 & 0.07 & 0.05 & 0.30 & 0.44 & 0.81 \\
\hline Peri & & ND & ND & ND & ND & ND & ND & ND & ND & ND & ND \\
\hline Pheo & & 0.01 & 0.01 & 0.07 & 0.11 & 0.19 & 0.18 & 0.11 & 1.42 & 1.44 & 2.07 \\
\hline PLFAs & $\mu \mathrm{g}-\mathrm{C} \cdot \mathrm{gdw}^{-1}$ & & & & & & & & & & \\
\hline i-C14:0 & & ND & 0.01 & 0.01 & 0.03 & 0.03 & 0.03 & 0.03 & 0.07 & 0.09 & 0.13 \\
\hline i-C15:0 & & 0.01 & 0.03 & 0.06 & 0.13 & 0.17 & 0.13 & 0.12 & 0.26 & 0.29 & 0.58 \\
\hline ai-C15:0 & & ND & 0.04 & 0.10 & 0.20 & 0.31 & 0.29 & 0.27 & 0.40 & 0.49 & 0.72 \\
\hline C16:1w7c & & 0.01 & 0.10 & 0.20 & 0.38 & 0.54 & 0.52 & 0.64 & 1.02 & 1.09 & 1.82 \\
\hline $\mathrm{C} 16: 4 \omega 1$ & & $\mathrm{ND}$ & 0.01 & 0.01 & 0.03 & 0.04 & 0.03 & 0.03 & 0.09 & 0.04 & 0.16 \\
\hline i-C17:0 & & 0.02 & 0.02 & 0.01 & ND & 0.01 & ND & ND & ND & ND & ND \\
\hline ai-C17:0 & & 0.02 & 0.03 & 0.01 & 0.01 & 0.02 & 0.02 & 0.02 & 0.09 & 0.08 & 0.10 \\
\hline $\mathrm{C} 18: 1 \omega 7 \mathrm{c}$ & & 0.01 & 0.09 & 0.22 & 0.36 & 0.47 & 0.43 & 0.56 & 1.18 & 0.98 & 1.81 \\
\hline $\mathrm{C} 20: 5 \omega 3$ & & ND & 0.08 & 0.17 & 0.11 & 0.07 & 0.10 & 0.25 & 0.47 & 0.46 & 0.43 \\
\hline $\mathrm{C} 22: 6 \omega 3$ & & 0.02 & 0.01 & 0.01 & 0.10 & 0.04 & 0.07 & 0.18 & 0.41 & 0.35 & 0.28 \\
\hline
\end{tabular}




\subsection{Particulate Organic Matter quality}

Pigment-derived parameters, CHLA/PHAEOs and ITPIG are presented in Fig. 3, the PLFA composition in Fig. 4 and the CN-ratio in Fig. 5.

In SPM samples, the chlorophyll $a$ to phaeopigments ratio (CHLA/PHAEOs) was quite variable, the highest value was found at St. $30(44.2 \pm 2.5)$ and the lowest at St. $20(2.9 \pm 0.3)$. At St. 02, 11 and 17, this ratio was around $18.4 \pm 1.0$ on average, while at St. 52, 62 and 65, it was around $32.0 \pm$ 1.2. Contrary to CHLA/PHAEOs, the intact to total pigments ratio (ITPIG) was relatively constant over the stations, with an average value of $0.59 \pm 0.05$.

The PLFA composition was relatively constant between stations and characterised by a high percentage of PUFA (58\% on average). SFA and MUFA contributed 26 and $15 \%$ to total PLFAs on average, while Br-FA contributed less than 1\%, except at St. 20 where it accounted for $4 \%$ to total PLFAs. The CN-ratio was relatively constant, averaging $6.1 \pm 0.4$. The highest value was found at St. 20 (6.9).

In SS samples, the chlorophyll a to phaeopigments and the intact to total pigments ratio showed low values, especially the former (Fig. 3). Both pigment-derived parameters decreased from St. 02 to St. 65 (Fig. 3). The composition of the PLFA pool was dominated by MUFA (40\% on average) at all stations, except St. 02, where it was characterised by PUFA and SFA (44\% and $41 \%$ of the total PLFA pool, respectively) (Fig. 4b). At the other stations, the percentages of SFA were relatively constant ( $25 \%$ on average). The percentages of MUFA and Br-FA were the highest at St. 20 (43\% and 24\%, respectively) and St. 30 (43\% and 22\% respectively) and the percentages of PUFA, the lowest (10\% and $11 \%$, respectively). The CN-ratio increased from St. 02 (6.2) to St. 65 (9.8) (Fig. 5).

The difference between SPM and SS samples varied between stations and between parameters (Fig. 6). For the pigment derived parameters (CHLA/PHAEOs and ITPIG), the difference between SPM and SS samples was positive and higher in the northernmost stations (St. 30, 
52, 62 and 65) compared to the southernmost stations (from St. 02 to 20) and St. 42. A similar trend was observed for the CN-ratio but the difference between SPM and SS was negative. The difference of PUFA was positive and increased from St. 02 to St. 30, followed by a decrease to St.52 and a slight increase to St. 65. The difference of MUFA was positive at St. 02 and negative at the other stations, and decreased from St. 02 to St. 30 before it slightly increased to St. 52 and decreased again to St. 65 as did the difference of Br-FA. The difference of SFA between SPM and SS samples varied between stations and was positive at St. $07,11,17,52$ and 65 , and negative at the other stations $(<-5 \%$ at St. 20, 30, 42 and 62, and about $-15 \%$ at St. 02).

\subsection{Principal Component Analysis}

The PCA results on POM quality parameters are presented in Fig. 7. The first PCA axis explains $81 \%$ of total variation. This axis separates the SPM samples on the left, scoring negatively on this axis and the SS samples on the right, scoring positively on this axis except for SS of St. 02 and 07. The SPM samples are characterised by higher values of chlorophyll a to phaeopigments and intact to total pigments ratios (A and B), whereas the SS samples are characterised by higher values of SFA (C), MUFA (D), PUFA (E), Br-FA (F) and CN-molar ratio (G). The second axis of the PCA explains another $10 \%$ of the variation. The chlorophyll a to phaeopigments ratio (A) and the PUFAs (E) scored positively for SPM of St. 30, 62, 65, 17 and 52 and for SS of St. 52, 62 and 65. 


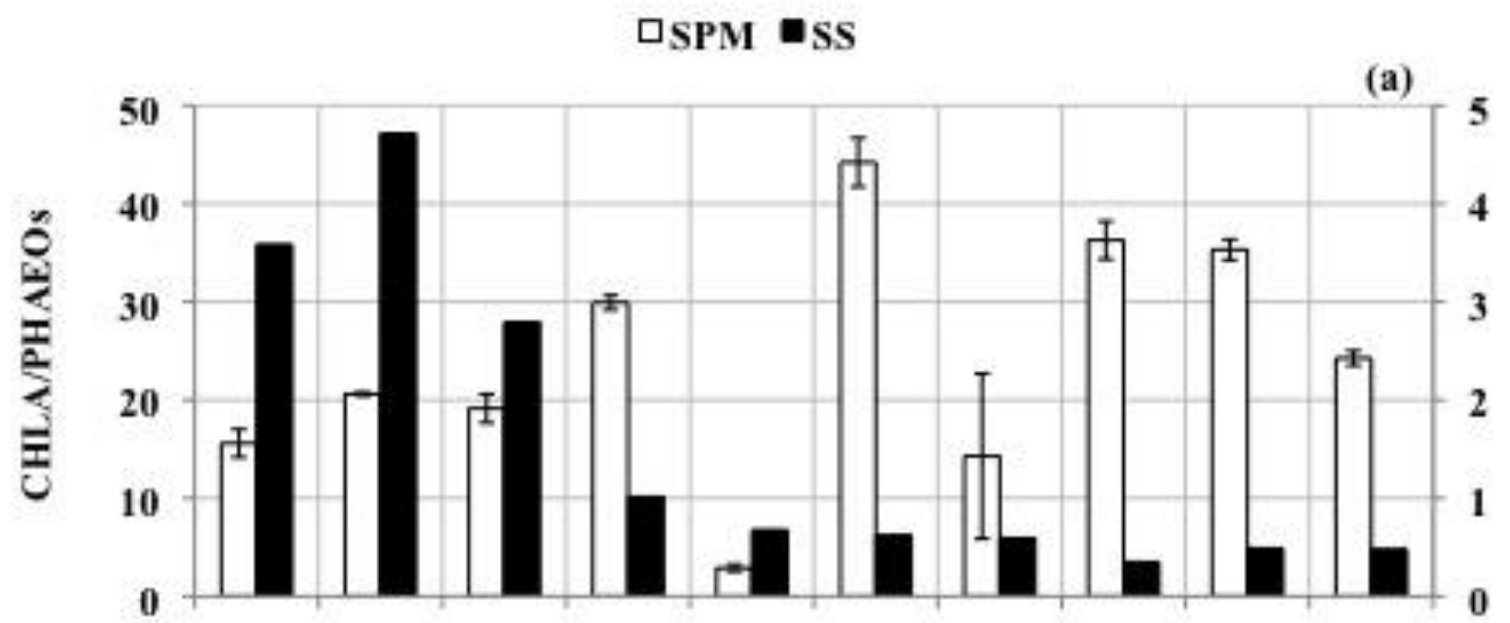

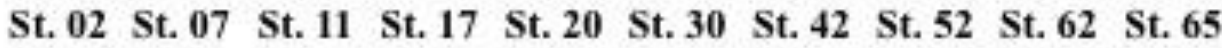

口SPM $\mathbf{a s S}_{\text {SS }}$

(b)

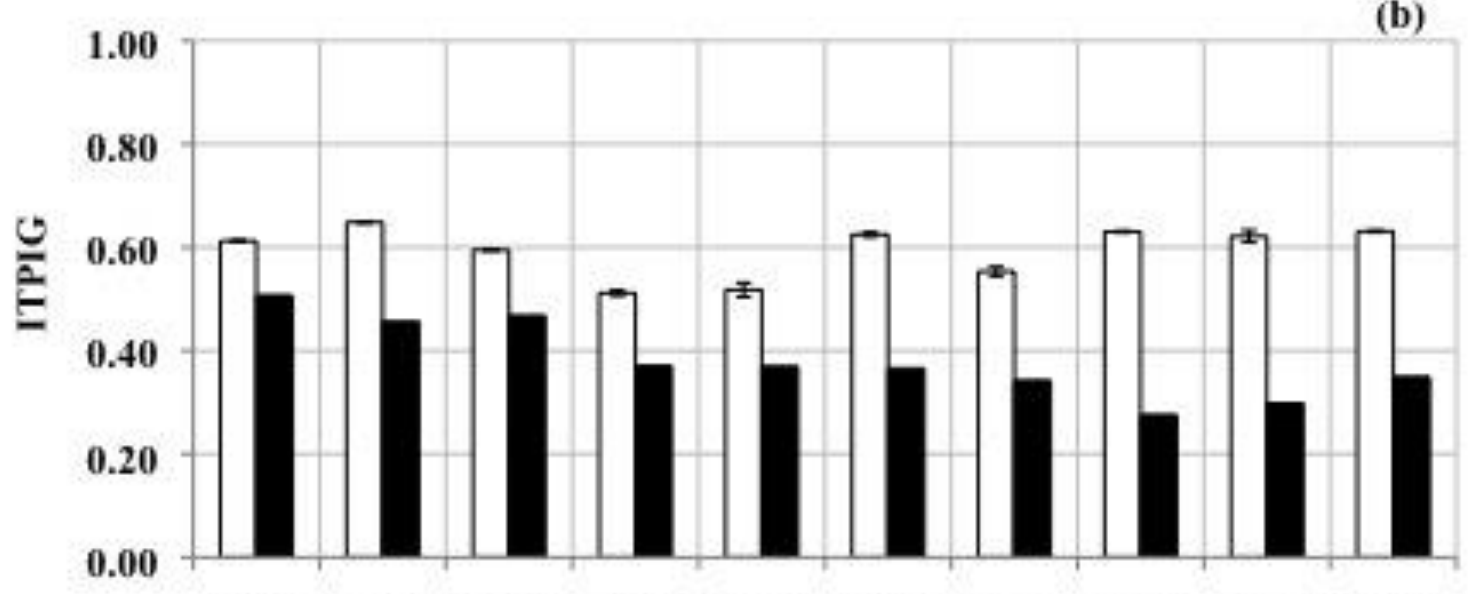

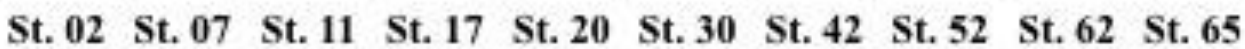

Fig. 3. (a) Chlorophyll $a$ to phaeopigments (CHLA/PHAEOs) and (b) intact to total pigments (ITPIG) ratios for SPM (white bars) and SS (black bars) samples. Note the different scale between SPM (left axis) and SS samples (right axis) for CHLA/PHAEOs. 


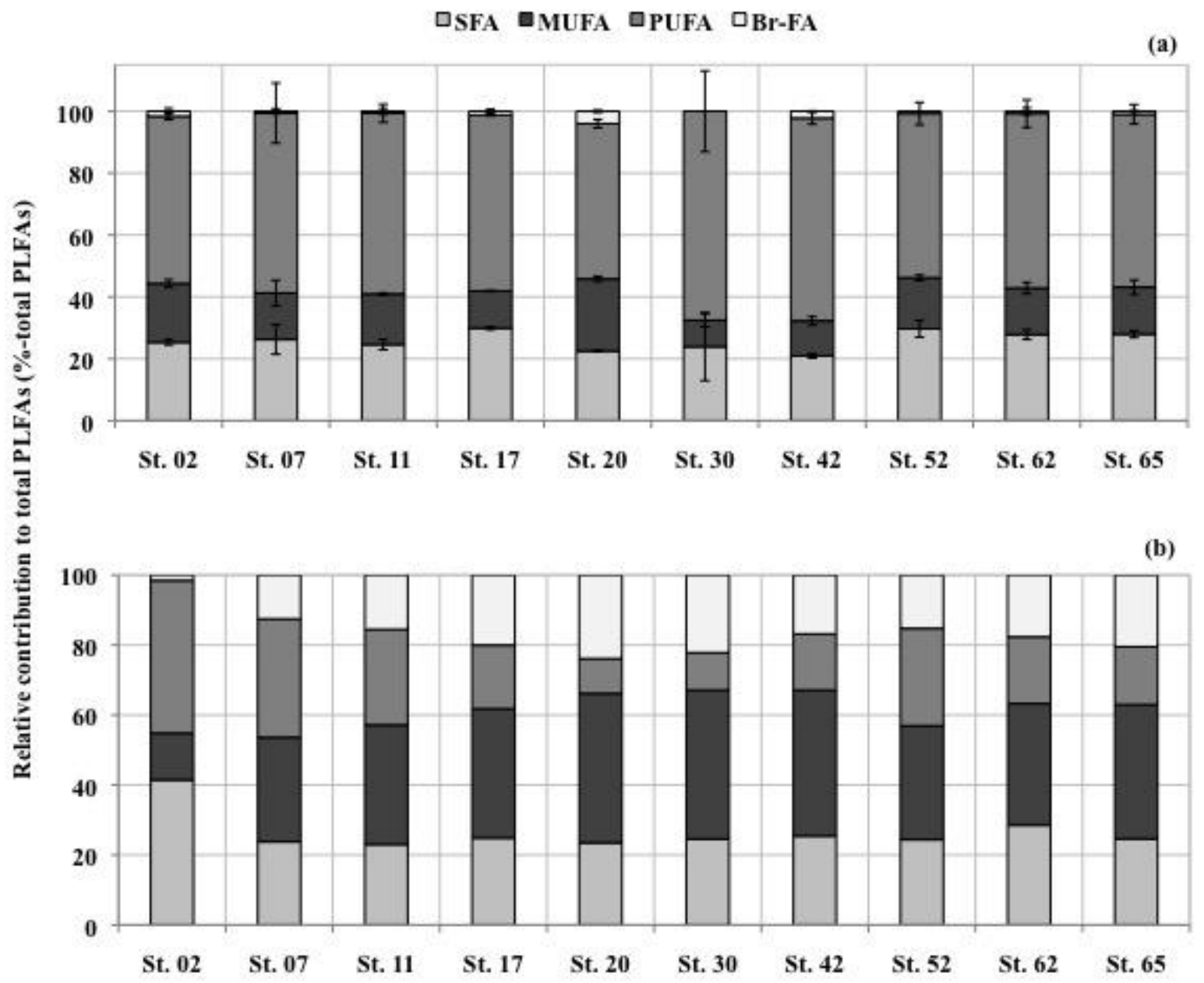

Fig. 4. Cumulative contribution of saturated fatty acid (SFA), mono-unsaturated fatty acid (MUFA), branched fatty acid (Br-FA) and poly-unsaturated fatty acid (PUFA) to total phospholipid derived fatty acid (PLFAs) in SPM (a) and SS (b) samples. 


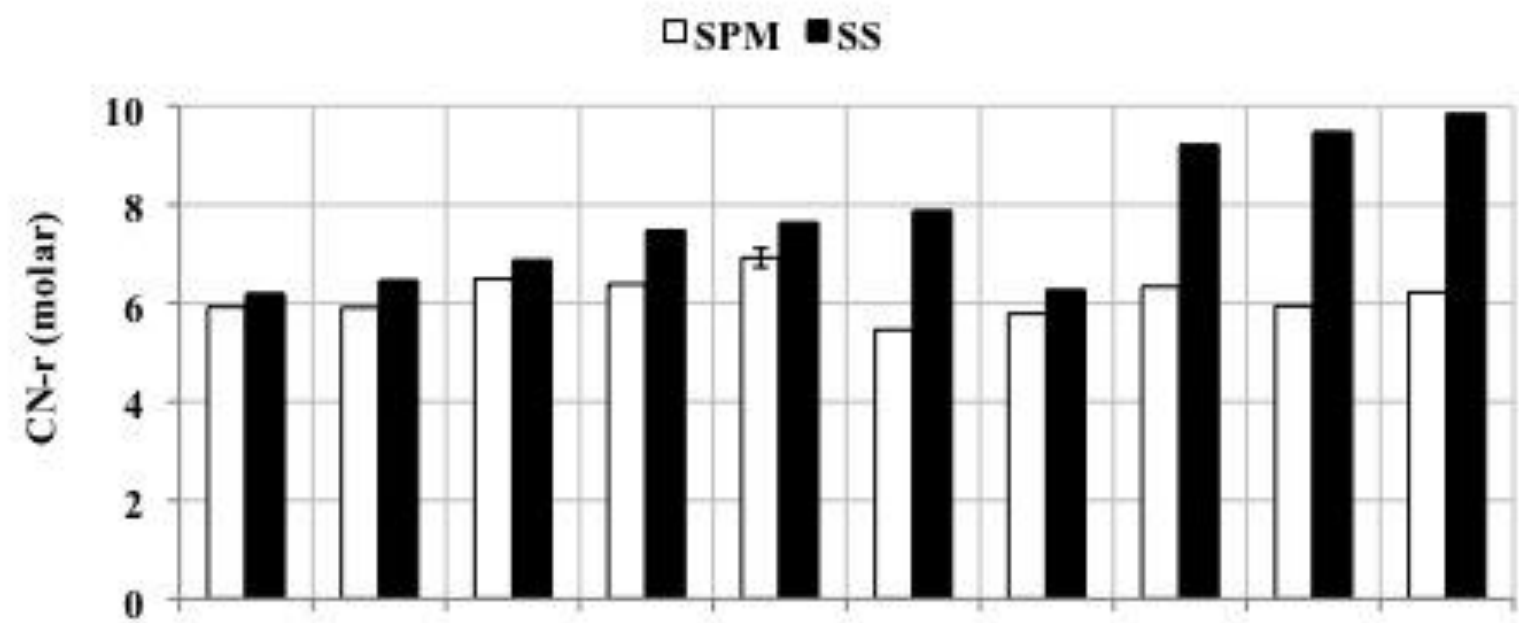

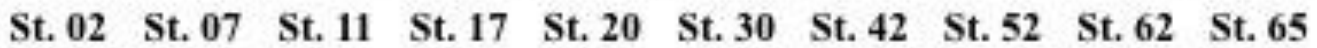

Fig. 5. Carbon to nitrogen molar ratio (CN-r) in SPM (white bars) and SS (black bars) samples. 

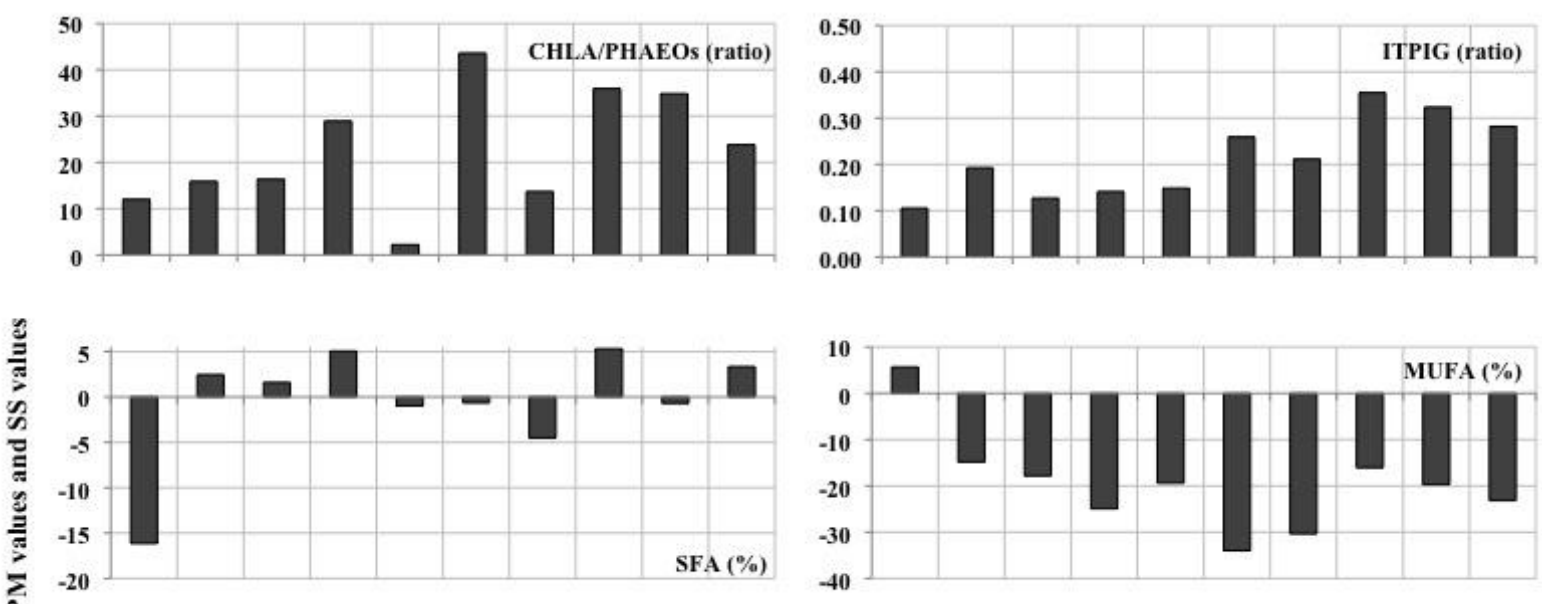

$$
\text { क् }
$$
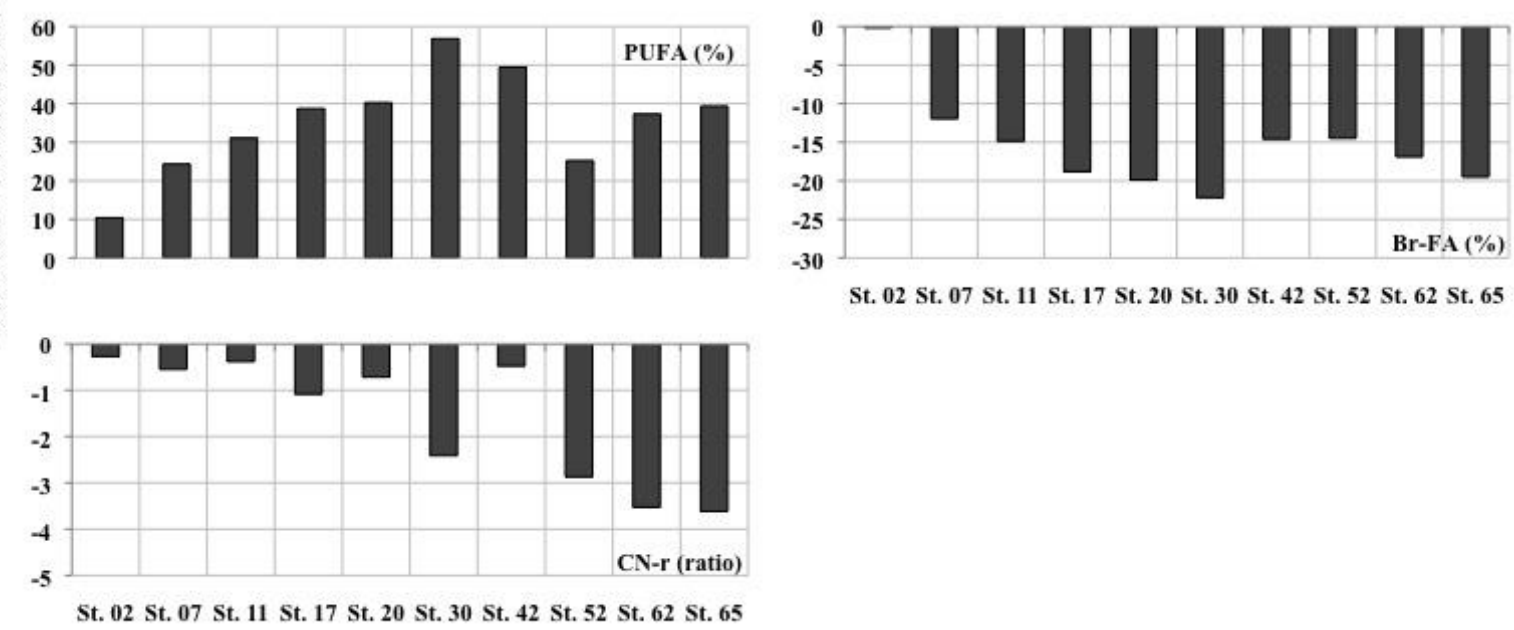

Fig. 6. Difference between SPM and SS values for each POM quality parameters (i.e. CHLA/PHAEOs, ITPIG, SFA, MUFA, PFA, Br-FA and CN-r). 


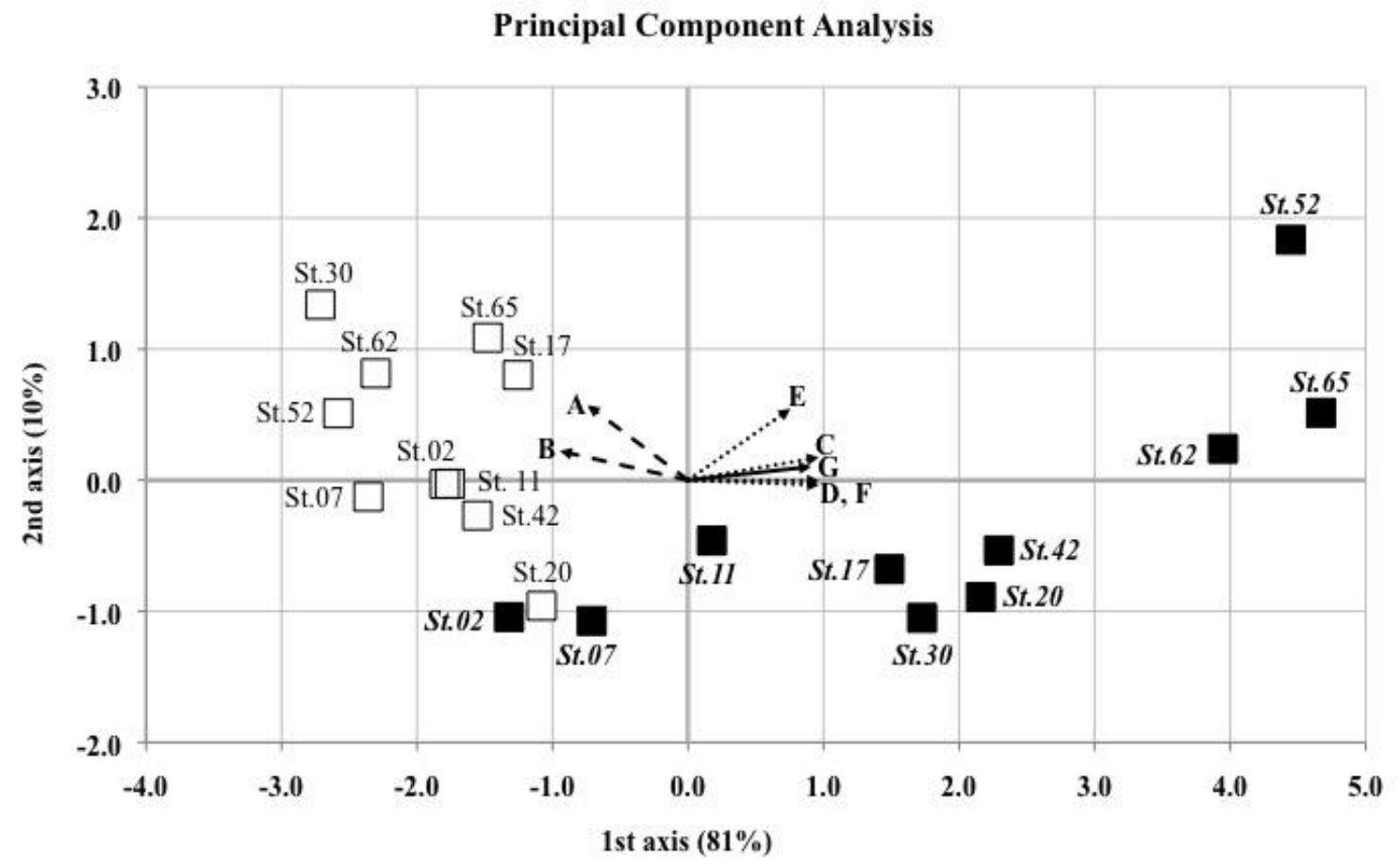

Fig. 7. Plot of the Principal Component Analysis (PCA) for SPM (white squares) and SS (black squares) samples. Arrows represent the different POM quality derived parameters calculated for SPM and SS samples over various time scales: A = chlorophyll $a$ to phaeopigments ratio and $\mathrm{B}=$ intact to total pigments ratio ('short time scale', dashed line); $\mathrm{C}$ = saturated fatty acid, $\mathrm{D}=$ mono-unsaturated fatty acid, $\mathrm{E}=$ poly-unsaturated fatty acid and $\mathrm{F}$ = branched fatty acid ('intermediate time sale', dotted line); and $\mathrm{G}=$ carbon to nitrogen ratio ('long time scale', solid line).

\section{Discussion}

Although the North Sea is a well-studied area, previous investigations usually focused either on OM transport at specific sites (e.g. Kattegat and Skagerrak - De Haas and Van Weering, 1999; Oyster Grounds - Van Raaphorst et al., 1998) or OM degradation in the sediment using one or two classes of specific biomarkers (e.g. amino acids and hexosamines - Dauwe and Middelburg, 1998; phytopigments - Boon et al., 1998; phospholipid fatty acids - Stoeck et al., 2002). To our best knowledge, this is the first time that several molecular biomarkers in 
both SPM and SS samples are analysed at 10 stations located along the transport route of OM in the North Sea. Our results are discussed in terms of POM composition, POM quality, and the factors controlling POM quality both in the water column and the surface sediment.

\subsection{Particulate Organic Matter composition.}

\subsubsection{In the surficial seawater}

Our SPM samples, taken at $5 \mathrm{~m}$ depth, showed a mean organic carbon concentration of 0.19 mg. $1^{-1} \pm 0.14$, which was consistent with data found by Kuerten (2010) during the same period (Tab. 2). At St. 20 , the POC concentration was relatively high $\left(0.58 \mathrm{mg} . \mathrm{l}^{-1} \pm 0.16\right)$ due to its location close to the Elbe estuary (Middelburg and Herman, 2007). The individual pigment and PLFA concentrations indicated the presence of diatoms in our SPM samples. At all stations, chlorophyll $a$ and fucoxanthin, biomarkers for diatoms (Wright and Jeffrey, 1987; Wright et al., 1991) were found in high concentrations as well as C20:5 13 , a known diatom biomarker (Volkman et al., 1989; Ahlgren et al., 1992; Dunstan et al., 1993) (Tab. 2). The

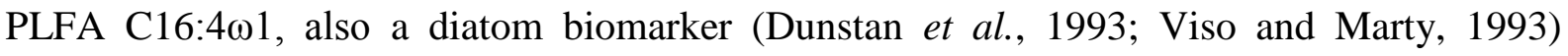
supported this at St. 02,11, 17 and 42. Furthermore, peridinin in pigments and C22:6 03 in PLFAs indicated the presence of dinoflagellates (Jeffrey, 1974; Dalsgaard et al., 2003) while the chlorophylls $b, c$ and $c_{3}$ were attributed to the presence of chlorophytes (Jeffrey, 1976). These results, reinforced by a CN-molar ratio of on average $6.1 \pm 0.4$ (Fig. 5) were consistent with the typical organic matter composition in marine phytoplankton (Henrichs, 2005) and a clear reflection of basin-wide primary production. Our SPM samples also contained the PLFA C18:1 $17 \mathrm{c}$ and in lower concentrations at some stations the PLFAs i-C15:0, ai-C15:0 and iC17:0. These PLFAs are known biomarkers for bacteria: the first denoting the presence of Gram-negative Proteobacteria (Braeckman et al., 2012), the latter indicative for CytophagaFlavobacteria and Gram-positive bacteria (Dalsgaard et al., 2003). The PLFA C16:167c was 
also found in our SPM samples in relatively high concentrations $\left(0.18 \mu \mathrm{g}-\mathrm{C} .1^{-1} \pm 0.07\right)$. This PLFA can be attributed either to diatoms or bacteria (Dalsgaard et al., 2003). Compound specific carbon isotope analysis of $\mathrm{C} 16: 1 \omega 7 \mathrm{c}$ indicated that this PLFA was dominantly from bacterial origin (data not shown).

\subsubsection{Surface sediment}

Pigment and PLFA composition in SS samples reflected findings in the SPM samples. Here also, chlorophyll $a$ and fucoxanthin exhibited relatively large concentrations at all stations,

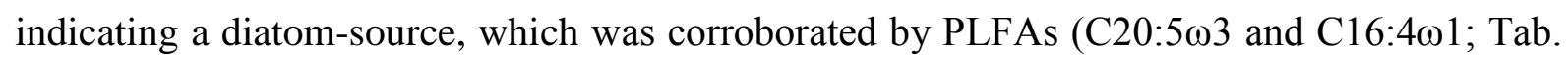
3). The absence of peridinin and the other chlorophylls (chlorophylls $b$ and $c_{3}$ ) however, suggested either that dinoflagellates and chlorophytes did not reach the seafloor or degraded faster than diatom-derived material. Pigment composition in SS samples was also characterised by increasing concentrations of chlorophyll a degradation products, i.e. pheophytin $a$ and phaeophorbide $a$, from St. 02 to St. 65 (Tab. 3). Moreover, SS samples contained high concentrations of $\mathrm{C} 16: 1 \omega 7 \mathrm{c}$. Like in SPM, $\delta^{13} \mathrm{C}-\mathrm{C} 16: 1 \omega 7 \mathrm{c}$ indicated that this PLFA was from bacterial origin (data not shown). This was reinforced by the relatively high concentrations of individual PLFA biomarkers typical for bacteria, such as C18:167c (Tab. 3) and by the increase of MUFA in SS samples compared to SPM samples (Fig. 4). Bechtel and Schubert (2009) attributed high percentages of MUFA to enhanced contributions from bacterial lipids. Summarising, the POM composition in SS was a mixture of OM of phytoplankton and bacterial origin.

No evidence of terrestrial-derived POM was found, even in the stations receiving freshwater input (lower salinity at St. 20, 52, 62 and 65). This may partly be due to the choice of biomarkers analysed, but our unpublished stable carbon and nitrogen isotope analysis of bulk 
organic matter, and compound specific isotope analyses of PLFAs indicate that the POM in this study was primarily from marine origin.

\subsection{Particulate Organic Matter transport processes}

\subsubsection{Vertical transport of POM}

The similarity in POM composition of surface waters and underlying sediments clearly indicate that POM from the surface seawater was deposited on the sediments. The organic compounds analysed have different rates of degradation (Cowie and Hedges, 1994; Dauwe and Middelburg, 1998; Woulds and Cowie, 2009, Veuger et al., 2012) and this allows to assess the degradation state of POM in the water column and in surface sediments over several time scales.

The results indicate that POM was fresher in SPM than in SS samples at all stations. In short, CHLA/PHAEOs and ITPIG were higher in SPM than SS samples (Fig. 3), while also the PLFA composition changed, with lower concentrations of PUFA and higher concentrations of MUFA and SFA in SS samples (Fig. 4). Since PUFA are less resistant to diagenetic degradation than MUFA and SFA (Farrington et al., 1988; Wakeham and Canuel, 1990), this indicates more degraded POM on the top of the sediments. In addition, Br-FA in sediments increased at all stations suggesting a higher contribution of bacterial OM (Bechtel and Schubert, 2009) (Tab. 3, Fig. 4b). Moreover, during initial stages of OM degradation, the CNmolar ratio of POM from marine origin usually increases due to the preferential degradation of N-rich components (Middelburg and Herman, 2007); and higher CN ratios were observed at all stations in SS compared to SPM samples (Fig. 5).

However, the difference between SPM and SS samples varied between stations and between POM quality parameters (Fig. 6). On average, the highest differences between SPM and SS samples were found at St. 30, 62 and 65, where organic matter was in a more advanced 
degraded state compared to the suspended organic matter. Such results were expected as St. 30 is located in the Oyster Grounds, a semi-depositional area (Otto et al., 1990) and St. 62 and 65, the deepest stations are at the end of the sedimentary OM transport route (Lohse et al., 1995; Van Raaphorst and Malschaert, 1996; Dauwe and Middelburg, 1998; Fig.1). The large difference between SPM and SS samples for the CN-molar ratio at St. 62 and 65 can be explained by the importance of an older fraction in the SS samples (Fig. 5 and 6). Indeed it has been reported that the major fraction (53 to 63\%) of the total suspended matter of the North Sea is deposited in the Skagerrak (Eisma, 1990; Dauwe and Middelburg, 1998) and this is highly degraded. Particulate organic matter undergoes remineralisation while settling vertically through the water column, therefore the deeper is the water column, the more degraded the POM reaching the seafloor. Furthermore these stations (St. 62 and 65) seemed to receive a larger share of freshwater inputs (lower salinity, Tab. 1), although no evidence of substantial quantities of terrestrial-derived OM was observed.

For the other parameters, except SFA and ITPIG, the highest difference between SPM and SS samples were found at St. 30. Rapid remineralisation of recently-deposited organic matter (Van Raaphorst et al., 1998) and the deposition of POM from the upstream stations might explain this. In addition, St. 30 may also receive POM from the East Anglian Plume, transporting matter from river discharge and seafloor erosion, thus with an advanced degradation state (Dyer and Moffat, 1998).

The small difference of CHLA/PHAEOs between SPM and SS samples at St. 20 might be explained by the stormy weather the day of the sampling. Indeed stormy weather promotes the resuspension of the sediment especially at shallow depths (Tab. 1) (Gerritsen et al., 2001), and the water sampled at this station was turbid. This result might also be explained by river input as St. 20 is located in the German Bight, a region receiving freshwater from the Rhine, the Meuse and the Scheldt rivers (Eleveld et al., 2008). 


\subsubsection{Lateral transport of POC}

The decreasing OM quality in the sediments from the primary productive area (St. 02 and St. 07) to the main deposition area (St. 65) was already demonstrated by Dauwe and Middelburg (1998) based on samples taken in 1994 and 1996. These authors investigated the sediment OM degradation state using amino acids and hexosamines and developed the Degradation Index (DI), an amino acid based index used as OM quality indicator. Our samples, taken more than 10 years later show similar trends. All our POM quality parameters, i.e. the decrease in pigments derived parameters (Fig. 3), the decrease of PUFA and SFA and the increase MUFA and Br-FAs (Fig. 4b) and the increase in CN-molar ratio (Fig. 5) from St. 02 to 65 corroborated Dauwe and Middelburg (1998) results. All our parameters indicate increasingly higher relative contributions of degraded material from the primary production (St. 02 and 07) to the main deposition area at St. 65 , and thus confirmed the degradation gradient in $\mathrm{OM}$ quality along the general transport route of sedimentary organic matter in the southern North Sea (Lohse et al., 1995; Van Raaphorst and Malschaert, 1996; Dauwe and Middelburg, 1998). In contrast, it appears that there is no degradation gradient in the sea surface water from St. 02 to 65. Most of the POM quality parameters, such as ITPIG (Fig. 3b), the composition of the PLFA pool (Fig. 4a) and the CN-molar ratio (Fig. 5), were relatively constant in SPM and indicative of relatively fresh POM, i.e. a consistently lack of evidence for a substantial resuspended organic matter contribution. This was not true at St. 20, where evidence of resuspension was observed as mentioned above. The variation of CHLA/PHAEOs between stations (Fig. 3a) and especially its high values at St. 30, 52 and 62 can be attributed either to a rapid lateral transport from the primary production area (St. 02 and 07) to the main deposition area (St. 65) or to local primary production, which is more important than the possible advection of older material. 


\subsection{Factors controlling POM quality in the southern North Sea}

The above discussed results are summarised in the principal component analysis (PCA) presented in Fig. 7. Results clearly show a distinction between SPM and SS samples, indicating that OM quality in SPM and SS are not controlled by the same factors. The $1^{\text {st }}$ axis of the PCA separates OM with a fresh signature, mainly SPM samples, from those that harbour more degraded material, mainly SS. The SS samples from St. 02 and St. 07 are positioned near to the SPM samples, indicating their relatively fresh signature. The PCA confirms that POM quality was relatively constant in the surface seawater, or did not provide consistent results from the productive area (St. 02 and 07) to the main deposition area (St. 62) (Fig. 1). The $2^{\text {nd }}$ axis of the PCA, which explains another $10 \%$ of the variance in the data, relates to increasing CHLA/PHAEOs and PUFA for SPM at St. 17 and 30, and for both SPM and SS at St. 52, 62 and 65, indicating fresher OM in these samples compared to the others. Therefore the PCA also confirms (i) either a rapid lateral transport from the primary production area (St. 02 and 07) to the main deposition area (St. 65) or local primary production, which is more important than the possible advection of older material in SPM at St. 17, 30, 52, 62 and 65 and (ii) the deposition of relatively fresh OM on the surface sediments at St. 52, 62 and 65. Nevertheless, the first and second axes together position the SS according to the sedimentary OM transport route, from relative labile OM in the South (lower-left part of PCA) to more refractory in the North (upper-right PCA corner). The PCA clearly reveals the degradation gradient of POM quality in the sediments along the sedimentary OM transport route, where stations can be arranged in three groups: (i) the main primary productive area, i.e. St. 02 and 07, (ii) the conduit zone, comprising St. 11, 17, 20, 30 and 42, and (iii) the deposition area at the end of the transport route (St. 52, 62 and 65) with more degraded OM. It is remarkable that the indices that represents the shortest time-scales, CHLA/PHAEOs and ITPIG, are designated to be most distinguishing between water-column 
and sedimentary POM, while the composition of the PLFA pool (SFA, MUFA, PUFA and Br-FA) and the $\mathrm{CN}$-molar ratio, which averages over intermediate and longer time scales sets apart the sedimentary samples.

\section{Conclusion}

We investigated the biogeochemical signatures of POM in the waters and surface sediments in the southern North Sea via a multiproxy approach. Our study showed that POM quality is not controlled by the same factors in the water column and in the sediments. There is consistent ageing of OM both from the water towards the sediment, and in the sediment, along the sedimentary OM transport route (Fig. 8).

Our findings also show that exchange of material between the water column and the underlying sediment is important especially in the productive area. The divergence in quality of $\mathrm{OM}$ in water and sediment from the southwest to the northeast of the North Sea seem to indicate a lower degree of benthic-pelagic coupling along the transport axis (Fig. 8). However, occasionally, intense benthic-pelagic coupling can be observed, as is the case for the Skagerrak stations where strong deposition of diatoms was observed, and for a station in the German Bight where storm-induced resuspension significantly diluted the pelagic POM with sedimentary material (Fig.8). If lateral transport rather than in situ production would be of increasing importance along the transport route, we would expect to see a difference between the POM quality from the primary production to the main deposition area for both SPM and SS samples. Our results for the water column are not in line with this, as the quality does not display a clear spatial signal (Fig. 8). 


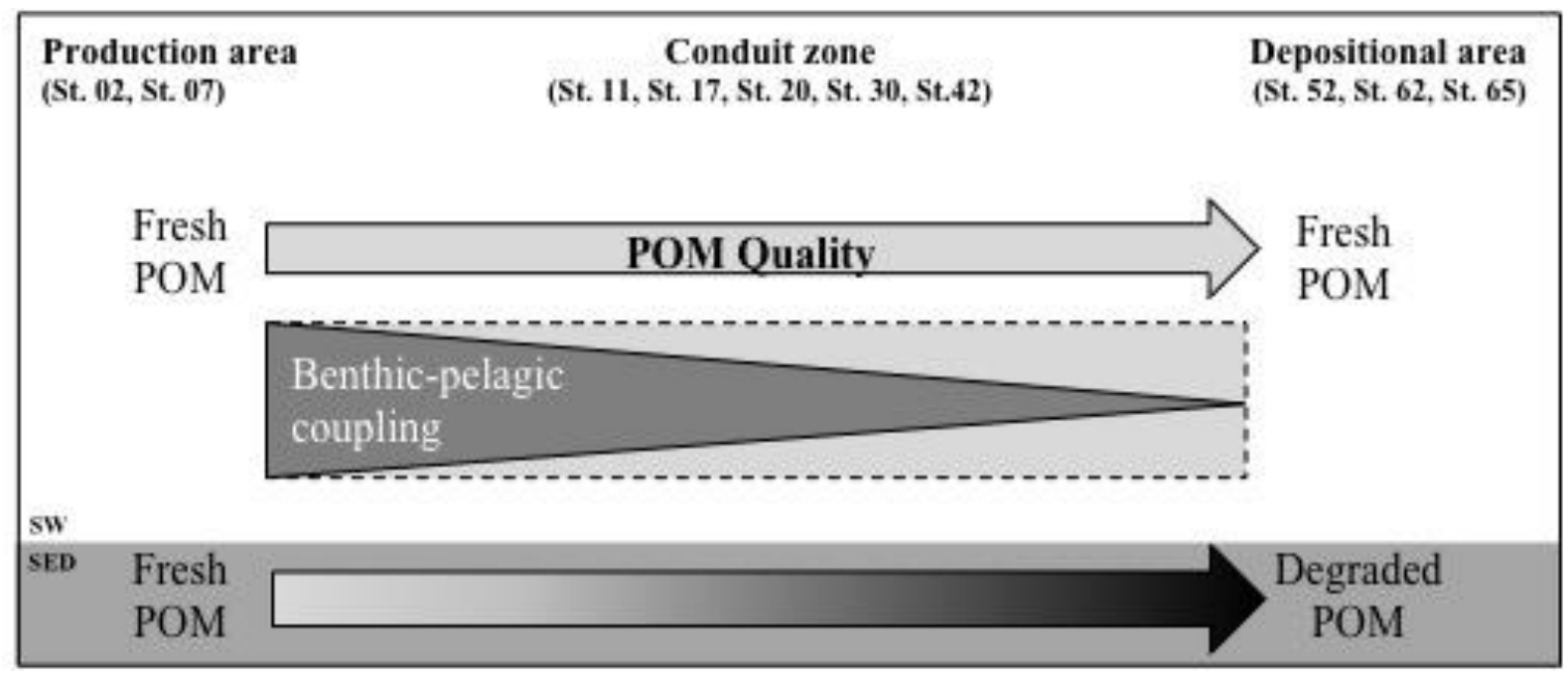

Fig. 8. Conceptual pictures of the main conclusions of this study. The arrows represent the quality of POM. The light gray means fresh, dark means degraded POM. The triangle shows the intensity of benthic-pelagic coupling, the dashed line rectangle represents the occasional event of intense benthic-pelagic coupling, which can occur along the sedimentary OM transport route, such as the deposition of fresh POM in the depositional area. SW = Sea Water, SED $=$ Sediment.

\section{Acknowledgement}

We thank the officers, crew and scientific party of the R.V. Pelagia for their support during the cruise and the analytical laboratory of NIOZ-YE for their advices and for performing the analyses. We are also grateful to Thomas Bianchi and two anonymous reviewers for their constructive comments on this manuscript. This project is part of the FOKUZ program and is a contribution of the Netherlands Center for Earth System Sciences.

\section{Terms and acronyms}

Br-FA - Branched fatty acid

CHLA/PHAEOs - Chlorophyll a to phaeopigments ratio

$\mathrm{CN}-\mathrm{r}-\mathrm{Carbon}$ to nitrogen ratio 
ITPIG - Intact to total pigments ratio

MUFA - Monounsaturated fatty acid

$\mathrm{OM}$ - Organic matter

PCA - Principal component analysis

PLFA - Phospholipid derived fatty acid

POC - Particulate organic carbon

POM - Particulate organic matter

PUFA - Polyunsaturated fatty acid

SFA - Saturated fatty acids

SPM - Suspended particulate matter

SS - Surface sediment

St. - Station 


\section{References}

Ahlgren, G., Gustafsson, I.B., Boberg, M., 1992. Fatty acid content and chemical composition of freshwater microalgae. Journal of Phycology 28, 37-50.

Bechtel, A., and Schubert, C.J., 2009. Biogeochemistry of particulate organic matter from lakes of different trophic levels in Switzerland. Organic Geochemistry 40, 441-454.

Bianchi, T.S., 2011. The role of terrestrially derived organic carbon in the coastal ocean: A changing paradigm and the priming effect. Proceedings of the National Academy of Sciences 108 (49), 19473-19481.

Bianchi, T.S., Canuel, E.A., 2011. Chemical Biomarkers in Aquatic Ecosystems. Princeton University Press, pp.396.

Bligh, E.G., Dyer, W.J., 1959. A rapid method for total lipid extraction and purification. Canadian Journal of Biochemistry and Physiology 37, 911-917.

Boon, A.R., Duineveld, G.C.A., Berghuis, E.M., van der Weele, J.A., 1998. Relationships between benthic activity and the annual phytopigment cycle in near-bottom water and sediments in the southern North Sea. Estuarine, coastal and shelf science 46, 1-13.

Borges, A.V., 2005. Do we have enough pieces of the jigsaw to integrate $\mathrm{CO}_{2}$ fluxes in the coastal ocean? Estuaries 28 (1), 3-27.

Boschker, H.T.S., De Brouwer, J.F.C., Cappenberg, T.E., 1999. The contribution of macrophyte derived organic matter in microbial biomass in salt marsh sediments: Stable carbon isotope analysis of microbial biomarkers. Limnology and Oceanography 44, 309319.

Braeckman, U., Provoost, P., Sabbe, K., Soetaert, K., Middelburg, J.J., Vincs, M., Vanaverbeke, J., 2012. Temporal dynamics in the diet of two marine polychaetes as inferred from fatty acid biomarkers. Journal of Sea Research 68, 6-19.

Budge S.M., Iverson S.J., Koopman H.N., 2006. Studying trophic ecology in marine 
ecosystems using fatty acids: a primer on analysis and interpretation. Marine Mammal Sciences 22, 759-801.

Christodoulou, S., Marty, J.-C., Miquel, J.-C., Volkman, J.K., Rontani, J.-F., 2009. Use of lipids and their degradation products as biomarkers for carbon cycling in the northwestern Mediterranean Sea. Marine Chemistry 113, 25-40.

Codispoti, L.A., Brandes, J.A., Christensen, J.P., Devol, A.H., Naqvi, S.W.A., Paerl, H.W., Yoshinari, T., 2001. The oceanic fixed nitrogen and nitrous oxide budgets: moving targets as we enter the anthropocene? Sciences Marine 65, 85-105.

Cowie, G.L., Hedges, J.I., 1994. Biochemical indicators of diagenetic alteration in natural organic-matter mixtures. Nature 369 (6478), 304-307.

Dalsgaard, J., St John, M., Kattner, G., Muller-Navarra, D., Hagen, W., 2003. Fatty acid trophic markers in the pelagic marine environment. Advances in Marine Biology 46, $225-340$.

Dauwe, B., Middelburg, J.J., 1998. Amino acids and hexosamines as indicators of organic matter degradation state in North Sea sediments. Limnology and Oceanography 43, 782 798.

De Haas, H., 1997. Transport, preservation and accumulation of organic carbon in the North Sea. Thesis. Utrecht University. pp. 149.

De Haas, H., Van Weering, T.C.E., 1999. Recent sediment accumulation, organic carbon burial and transport in the northeastern North Sea. Marine geology 136, 173-187.

Dobrynin, M., Gayer, G., Pleskachevsky, A., Günther, H., 2010. Effect of waves and currents on the dynamics and seasonal variations of suspended particulate matter in the North Sea. Journal of Marine Systems 82, 1-20.

Dunstan, G.A., Volkman, J.K., Barrett, S.M., Leroi, J., Jeffrey, S., 1993. Essential polyunsaturated fatty acids from 14 species of diatom (Bacillariophyceae). 
Phytochemistry 35, 155-161.

Dyer, K.R., Moffat, T.J., 1998. Fluxes of suspended matter in the East Anglian Plume Southern North sea. Continental Shelf Research 18, 1311-1331.

Eisma, D., 1990. Transport and deposition of suspended matter in the North Sea and relation to coastal siltation, pollution, and bottom fauna distribution. Review of Aquatic Science $3,181-216$.

Eleveld, M.A., Pasterkamp, R., van der Woerd, H.J., Pietrzak, J.D., 2008. Remotely sensed seasonality in the spatial distribution of sea-surface suspended particulate matter in the southern North Sea. Estuarine, Coastal and Shelf Science 80, 103-113.

Farrington, J.W., Davis, A.C., Sulanowski, J., McCaffrey, M.A., McCarthy, M., Clifford, C. H., Dickinson, P., Volkman, J.K., 1988. Biogeochemistry of lipids in surface sediments of the Peru upwelling area at $15^{\circ} \mathrm{S}$. In: Mattavelli, L., Novelli, L. (Eds.), Advances in Organic Geochemistry 1987. Pergamon Press, Oxford, 607-617.

Gattuso, J.-P., Dawson, N.A., Duarte, C.M., Middelburg, J.J., 2005. Patterns of publication effort in coastal biogeochemistry: a bibliometric survey (1971 to 2003). Marine Ecology Progress Series 294, 9-22.

Gerritsen H., Boon, J.G., Van der Kaaij, T., Vos, R.J., 2001. Integrated modelling of suspended matter in the North Sea. Estuarine, Coastal and Shelf Science 53, 581-594.

Halpern, B.S., Walbridge, S., Selkoe, K.A., Kappel, C.V., Micheli, F., D’Agrosa, C., Bruno, J.F., Casey, K.S., Ebert, C., Fox, H.E., Fujita, R., Heinemann, D., Lenihan, H.S., Madin, E.M.P., Perry, M.T., Selig, E.R., Spalding, M., Steneck, R., Watson, R., 2008. A global map of human impacts on marine ecosystems. Science 319, 948.

Henrichs, S.M., 2005. Organic matter in coastal marine sediments. In: Robinson, A.R., Brink, K.H. (eds), 2005. The global coastal ocean: multiscale interdisciplinary processes. The Sea (13), Chap. 5: 129-163. 
Jeffrey, S.W., 1974. Profiles of photosynthetic pigments in the ocean using thin-layer chromatography. Marine Biology 26, 101-119.

Jeffrey, S.W., 1976. A report of green algal pigments in the central Atlantic Ocean. Marine Biology 37, 33-37.

Jeffrey, S.W., Mantoura, R.F.C., Wright, S.W., (Eds), 1997. Phytoplankton pigments in oceanography: guidelines to modern methods. Monographs on Oceanographic Methodology 10. UNESCO Publishing: Paris. ISBN 92-3-103275-5. 661 pp.

Kuerten, B., 2010. An end-to-end study of spatial differences in North food webs. Ph. D. thesis. University of Newcastle upon Tyne.

Lohse, L., Malschaert, J.F.P., Slomp, C.P., Helder, W., Van Raaphorst, W., 1995. Sedimentwater fluxes of inorganic nitrogen compounds along the transport route of organic matter in the North Sea. Ophelia 41, 173-197.

Middelburg, J.J., Herman, P.M.J., 2007. Organic matter processing in tidal estuaries. Marine Chemistry 106, 127-147.

Newbold, J.D., Elwood, J.W., O’Neill, R.V., Van Wiekle, V., 1981. Measuring nutrients spiralling in streams. Canadian Journal of Fisheries and Aquatic Science 38, 860-863.

Newbold, J.D., Mulholland, P.J., Elwood, I.W., O’Neill, R.V., 1982. Organic carbon spiralling in stream ecosystems. Oikos 38, 266-272.

Newbold, J.D., 1992. Cycles and spirals of nutrients. Chap.18 - p.379-408 in "The Rivers Handbook: hydrological and ecological principles”. Calow P. and Petts G.E., 1992. Ed. Oxford

Nieuwenhuize J., Maas, Y.E.M., Middelburg, J.J., 1994. Rapid analysis of organic carbon and nitrogen in particulate materials. Marine Chemistry 45, 217-224.

Otto, L., Zimmerman, J.T.F., Furnes, G.K., Mork, M., Saetre, R., Becker, G., 1990. Review of the physical oceanography of the North Sea. Netherlands Journal of Sea Research 26, 
$161-238$.

R Development Core Team, 2008. R: A language and environment for statistical computing. R Foundation for Statistical Computing, Vienna, Austria. ISBN 3-900051-07-0. URL: http://www.R-project.org.

Soetaert, K., Middelburg, J.J., Herman, P.M.J., Buis, K., 2000. On the coupling of benthic and pelagic biogeochemical models. Earth-Science reviews 51, 173-201 .

Stoeck, T., Kröncke, I., Duineveld, G.C.A., Palojärvi, A., 2002. Phospholipid fatty acid profiles at depositional and non-depositional sites in the North Sea. Marine Ecology Progress Series 241, 57-70.

Thomas, H., Bozec, Y., de Baar, H.J.W., Elkalay, K., Frankignoulle, M., Schiettecatte, L.-S., Kattner, G., Borges, A.V., 2005. The carbon budget of the North Sea. Biogeosciences (2), $87-96$.

Tiessen, M.C.H., Fernard, L., Gerkema, T., van der Molen, J., Ruardij, P., van der Weer, H.W., 2014. Numerical modelling of physical processes governing larval transport in the southern North Sea. Ocean Science 10, 357-376. doi:10.5194/os-10-357-2014.

Van Raaphorst, W., Malschaert, J., 1996. Ammonium adsorption in superficial North Sea sediments. Continental Shlef Research 16 (11), 1415-1435.

Van Raaphorst, W., Malschaert, J., Van Haren, H., 1998. Tidal resuspension and deposition of particulate matter in the Oyster Grounds, North Sea. Journal of Marine Research 56, 257-291.

Veuger, B., van Oevelen, D., 2011. Long-term pigment dynamics and diatom survival in dark sediment. Limnology and Oceanography 56 (3), 1065-1074.

Veuger, B., van Oevelen, D., Middelburg, J.J., 2012. Fate of microbial nitrogen, carbon, hydrolysable amino acids, monosaccharides, and fatty acids in sediment. Geochimica et Cosmochimica Acta 83, 217-233. 
Viso, A.C., Marty, J.C., 1993. Fatty acids from 28 marine microalgae. Phytochemistry 34, $1521-1533$.

Volkman, J.K., Jeffrey, S.W., Nichols, P.D., Rogers, G.I., Garland, C.D., 1989. Fatty acid and lipid composition of 10 species of microalgae used in marine culture. Journal of Experimental Marine Biology and Ecology 128, 219-240.

Wakeham, S.G., Canuel, E.A., 1990. Fatty acids and sterols of particulate matter in a brackish and seasonally anoxic coastal salt pond. Organic Geochemistry 16, 703-713.

Woulds, C., Cowie, G.L., 2009. Sedimentary pigments on the Pakistan margins: Controlling factors and organic matter dynamics. Deep-Sea Research II (56), 347-357.

Wright, S.W., Jeffrey, S.W., 1987. Fucoxanthin pigment markers of marine phytoplankton analysed by HPLC and HPTLC. Marine Ecology Progress Series 38, 259-266.

Wright, A., Wright, S.W., Jeffrey S. W., Mantoura, R.F.C., Llewellyn, C.A., Bjornland, T., Repeta, D., Welschmeyer, N., 1991. Improved HPLC method for the analysis of chlorophylls and carotenoids from marine phytoplankton. Marine Ecology Progress Series 77, 183-196. 